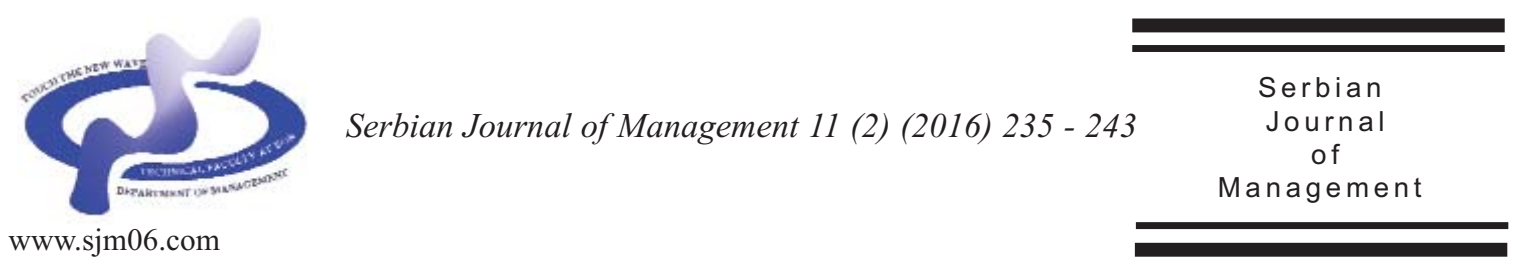

\title{
PROOF OBLIGATIONS AS A SUPPORT TOOL FOR EFFICIENT PROCESS MANAGEMENT IN THE FIELD OF PRODUCTION PLANNING AND SCHEDULING
}

\author{
Denisa Hrušecká* \\ Tomas Bata University in Zlin, Faculty of Management and Economics, Department of \\ Industrial Engineering and Information Systems, Czech Republic
}

(Received 27 May 2016; accepted 23 August 2016)

\begin{abstract}
Production planning and scheduling is one of the most important business processes that significantly influence the performance of manufacturing companies. There are many information systems supporting production planning and scheduling and some of them are based on very sophisticated planning algorithms. Despite this fact, many companies still face serious problems even while using professional software tools for production planning and scheduling. Obviously, a lot of other changes in form of process innovations are required.

This paper deals with the problem of process management in the field of production planning and scheduling. Our study explains reasons for low performance of advanced technologies and provides solution in form of system model of key factors affecting the efficiency of planning software. Research part is based on the study conducted within Czech manufacturing companies in form of questionnaire-based investigation combined with interviews.

Proposed solution is extended to the abstract mathematical model based on proof obligations which prove or disprove the correctness of intended algorithms. Our study provides basic example of such an abstract model and describes its functionality and influence to proper production planning and scheduling. It will be processed to the form of complex expert system based on Event B method in the future.
\end{abstract}

Keywords: Production Planning and Scheduling, Process Management, Proof Obligation, Production Process, Production System

\section{INTRODUCTION}

Production planning is one of the most important activities of production management and it significantly affects the whole production process performance. Some production processes are too complex to be managed without using some kind of

\footnotetext{
* Corresponding author: hrusecka@fame.utb.cz

DOI:10.5937/sjm11-11135
} 
advanced software tools for their planning and scheduling. However, each technology is always influenced by human factor and the level of integration with other business processes. Lihong and Shengping (2012) highlight the importance of integration of planning and scheduling for the purpose of increasing flexibility and total performance of production system. In the practice, very common conflict occurs between the sales process and process of production planning, which is caused by different priorities as Vidová (2009) explains.

The process of production planning and scheduling often crosses the borders of a single organization and influence the performance of the whole supply chain. Noonan and Wallace (2006) proved the fact that the horizontal cooperation within the whole supply chain helps to increase its flexibility and influence the planning process of each individual member. Therefore, the implementation of an advanced planning software helps to increase the performance of the whole supply chain as Jonsson et al. (2007) confirmed in their research.

The research study of Belás et al. (2015) showed that the most important business risk, that especially small and medium sized companies face, is market risk. That is why the need of companies to adapt to rapidly changing market environment is increasing. However, Nyhuis and Wiendahl (2009) point out conflicts between some production goals that must be considered during decision making processes. For example, increasing flexibility and higher utilization of production resources can cause higher production costs, higher level of inventories and related lower efficiency. Therefore, the business strategy must be clearly formulated in order to set all production goals and performance indicators in accordance with it
(Neely et al., 2002). All these facts influence also the right choice of advanced technology for production planning and scheduling and its future use.

Common database information systems sometimes fail in solving very complicated problems and making complex decisions. Jonsson and Ivert (2015) found out that planning environment and process maturity influence master production planning performance and supply and/or production uncertainty make it difficult to use production plan efficiently. On the other hand, a knowledge-based system (or expert system) is more suitable for solving very complex problems because it mimics the behaviour of a human expert and therefore it is able to provide more sophisticated solutions (Jackson, 1998). Weiss (1988) explain the purpose of knowledge base refinement which is a critical point of an expert system. It can be simply defined as the localisation of specific weaknesses in the system and improvement of its performance. Even-B method is one of the refinementbased methods for knowledge modelling. It has been used in major safety-critical system applications like emergency services, fire alarms, nuclear reactor control systems etc. It is a formal method that enables the abstraction of complex interactions between its subcomponents and mathematical verification of set rules. An Event-B model consists of contexts, machines and events defined by a set of constants, axioms, variables and invariants. Each event is a guarded command initializing some action (Abrial, 2010; Métayer et al., 2005; Mu, 2013). In this context it is useful to analyse the possibilities of Event-B modelling in the field of production planning and scheduling and related process management. 
2. RESEARCH OBJECTIVES AND METHODOLOGY

The aim of this paper is to analyse reasons for low performance of advanced information systems for production planning and scheduling and provide solution in form of system model of key factors affecting the efficiency of their planning algorithms. Proposed solution is extended to the abstract mathematical model based on Event-B method whose partial demonstration is also presented in this paper.

Research part is based on the study conducted within Czech manufacturing companies in form of questionnaire-based investigation combined with conversational interviewing in order to achieve higher reliability of gained results.

The questionnaire was sent to Czech companies which meet the following criteria:

- manufacturing company regardless the type of industry;

- company uses some type of information system for production planning and scheduling based on TOC principles and advanced planning algorithms (considering finite resources).

The sample included 68 completely filled questionnaires. The size structure of respondents was as follow: $8 \%$ were microenterprises, $50 \%$ were small enterprises, $20 \%$ were medium-sized enterprises and $22 \%$ were large companies. The industry structure of surveyed companies was very varied: the largest share was comprised of enterprises operating in mechanical engineering $(32 \%)$, electronic and electrical industry $(15 \%)$, non-specified manufacturing industry $(11 \%)$ or plastics industry $(7 \%)$. The consequent conversational interview was conducted in 13 Czech manufacturing companies, whose size and industry structure is very similar.

For evaluating the level of achieving expected benefits of the implemented advanced technology for production planning and scheduling, the following scientific hypothesis was set:

- H: Expected benefits of an implemented advanced technology for production planning and scheduling are not achieved by Czech manufacturing companies at least to $75 \%$.

The results of quantitative research were examined through Pearson statistics where pvalue was compared with the standard 5\% confidence level. Consequent qualitative research was used to prove statistic evaluation of the set hypothesis and to understand the problem more in depth in order to create system model the most precisely.

\section{RESULTS AND DISCUSSION}

In this section the main results of the quantitative and qualitative research are introduced together with proposed solutions for solving identified problems of running advanced software tools for production planning and scheduling.

\subsection{Evaluation of set hypothesis}

At the beginning of our study, we want to prove that many Czech manufacturing companies do not achieve expected outcomes and benefits after the implementation of selected information system for advanced planning and scheduling. Therefore, we formulated the following hypothesis, which was 
subsequently evaluated by the results of questionnaire-based investigation:

- H: Expected benefits of an implemented advanced technology for production planning and scheduling are not achieved by Czech manufacturing companies at least to $75 \%$.

Expected benefits of advanced information system for production planning and scheduling were divided into six categories which were evaluated separately (Table 1). Respondents were asked to state the level of achieving expected outcomes and benefits of the implemented information system on the scale from $0 \%$ to $100 \%$. Because of the fact that the normal distribution was not confirmed in all cases, the one-sample nonparametric median test (sign test) was used for statistic evaluation of the set hypothesis.

Because of the fact that all p-values (except the question of higher flexibility) are higher than the standard 5\% confidence level, the validity of set hypothesis cannot be simply rejected. It means that expected benefits of implemented IS for production planning and scheduling are not achieved at least to $75 \%$.

In order to strength the results of the research and increase the credibility and validity of data, methodological triangulation combining multiple methods to gather data was applied. It means that the results of quantitative investigation were evaluated by the consequent qualitative research realized in form of conversational interviewing. We spoke to CEOs or production managers from 13 different Czech manufacturing companies. All of them confirmed that they are not satisfied with the process of production planning and scheduling in their organization despite the fact they use advanced software support for this purpose. Moreover, the results of qualitative investigation provided us with the answers for why companies do not achieve $100 \%$ of expected outcomes and benefits from advanced technology for production planning and scheduling. The most often mentioned reasons are the following ones:

- high complexity in the field of synchronizing all key business processes;

Table 1. Statistical evaluation of expected benefits of advanced planning software

\begin{tabular}{|c|c|c|c|}
\hline Expected benefits of advanced planning software & $\begin{array}{l}\text { average \% } \\
\text { of achievement }\end{array}$ & $\begin{array}{l}\text { standard } \\
\text { deviation }\end{array}$ & p-value \\
\hline $\begin{array}{l}\text { Decreasing the number of re-planning cycles caused by } \\
\text { orders with higher priority }\end{array}$ & 62.11 & 22.25 & 0.99997 \\
\hline $\begin{array}{l}\text { Decreasing the total time of production planning } \\
\text { (time of preparation of the production plan) }\end{array}$ & 71.23 & 20.73 & 0.92622 \\
\hline Increasing the reliability of production plans & 74.41 & 20.54 & 0.59297 \\
\hline Shortening the lead time of one order & 57.91 & 24.47 & 1 \\
\hline Higher flexibility of production scheduling & 75.00 & 23.29 & 0,5 \\
\hline Decreasing production costs & 55.41 & 26.93 & 1 \\
\hline $\begin{array}{l}\text { Others (opened question, defined by respondents): } \\
\begin{aligned}- & \text { more proper measurement of labour productivity } \\
- & \text { automated communication with other software tools }\end{aligned}\end{array}$ & \multicolumn{3}{|c|}{$\begin{array}{l}\text { it was not evaluated, because of a low } \\
\text { number of respondents ( } 2 \text { answers) }\end{array}$} \\
\hline
\end{tabular}


- individual problems in internal business processes influencing the quality of input data;

- human factors (mistakes, low skills, ...).

Despite the fact that some authors (Chen \& Hasan, 2008; Sulová, 2009) mentioned the problem of selecting the appropriate technology for specific type of manufacturing system or unrealistic expectations of companies, we did not notice any of these facts in our respondents. Therefore, the following research activities are focused on dealing with internal issues that are major stumbling blocks in achieving maximum performance of the process of production planning and scheduling and using advanced software tools more efficiently.

\subsection{General system model}

As Goldratt says in the title of one of his bestsellers (Goldratt, 2000), information technology is necessary but not sufficient for being competitive in today's highly dynamic business environment. The results of our research activities, presented in the previous section, showed that advanced technology and the high level of process management are two inseparable conditions for efficient production planning and scheduling and achieving expected outcomes in form of high performance of the whole production system.

Therefore, some kind of general system model of key factors affecting the efficiency of advanced software tools for production planning and scheduling was created. It

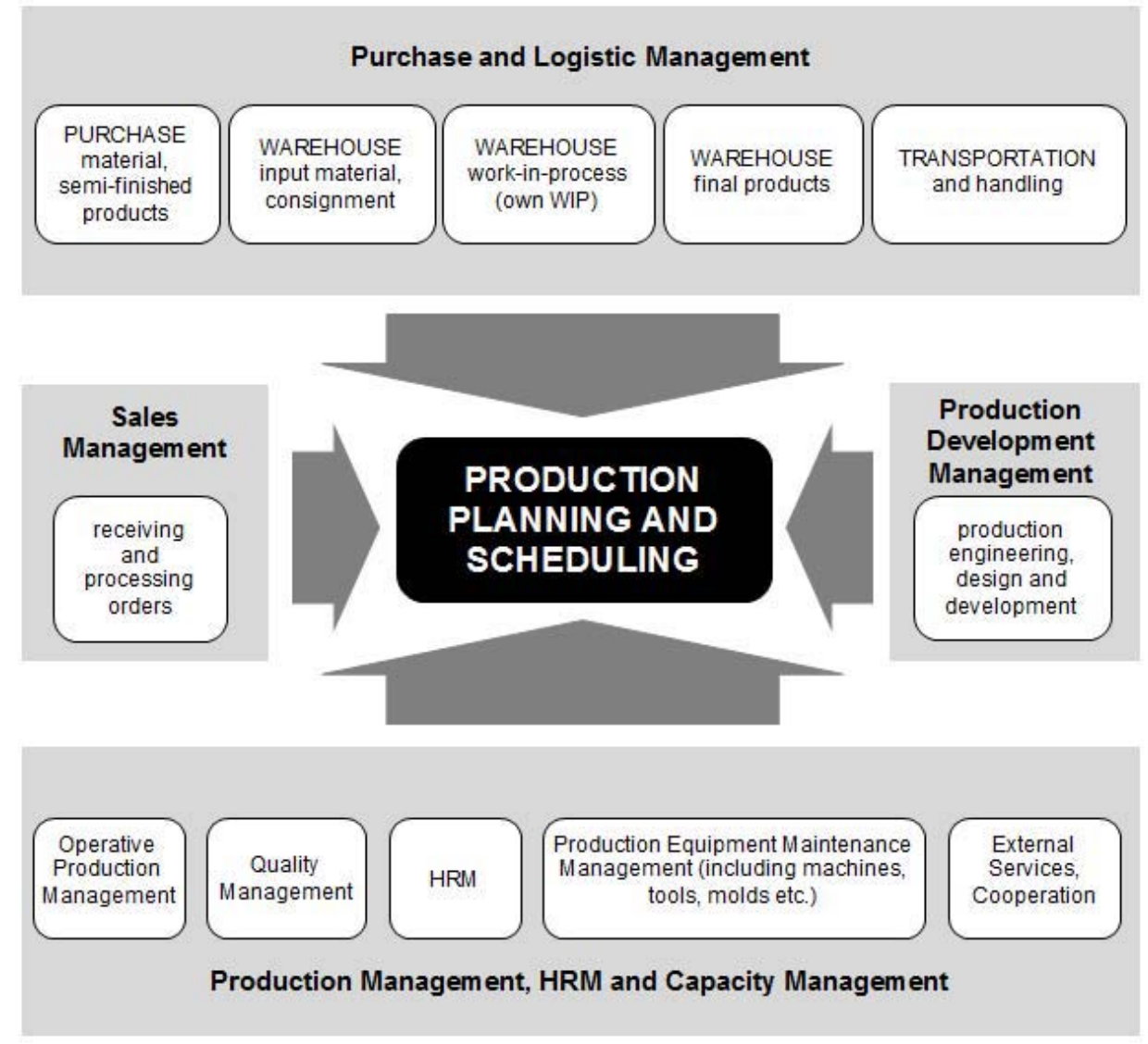

Figure 1. System model of key factors affecting production planning 
integrates four basic areas of company's management that must cooperate in order to achieve required results (Figure 1).

Each of the four basic areas showed in the picture above (Figure 1) includes several business processes that critically influence the process of production planning and scheduling in two different ways:

- they generate important inputs for production planning and scheduling such as customer requirements, routings, bills of material, work standards and average labour productivity, maintenance plans, utilization of production resources, real time information about the availability of material sources etc.

- they use outputs of the process of production planning and scheduling in order to satisfy customers' requirements in accordance with the production plan and its deadlines.

In order to ensure the high quality of inputs for production planning and scheduling (quality of data used by information system) and avoid human mistakes and other kinds of defects as much as possible, some kind of expert system or simplified principles of artificial intelligence tools can be included as a support tool for efficient process management. There is quite new method, called Event B, which seems to be very suitable for this type of problem. Its basic principles, rules for setting proof obligations and short example introducing a piece of our solution are presented in the following section.

3.3. Simple Basic mathematical EventB Model for Efficient Production Planning and Scheduling

The majority of available software tools for production planning and scheduling are based on standard database technology. Some of them include advanced planning algorithms combining forward and backward planning, they also work with finite and infinite resources, but they often miss some kind of advanced knowledge based algorithms (artificial intelligence principles) supporting decision making and helping to avoid repeated problems in production planning and scheduling process. Therefore, in this part of contribution, the potential of Event-B modelling in the process of production planning and scheduling will be shortly outlined.

Event-B method and its main logic were shortly explained in the introduction part. In the following section the simplified example of its possible usage in production planning and process management is presented. For the purpose of Event-B modelling, the problem must be defined by (Abrial, 2010):

- $\quad$ a set of constants and their axioms $=$ context

- a set of variables and invariants $=$ machine.

In our case, all the constants represent limitation of production planning and scheduling, for example maximum possible productivity of each machine, number of working hours per day, minimum required profit from each order etc. Then axioms describe individual constants. So, the initial context structure can be as follow:

CONTEXT Production

Planning

Limitations

$$
\text { CONSTANTS }
$$

$\max M 1$

production capacity of machine M1

minP // minimum profit from

one order needed for its acceptance

WR // wastage rate 
AXIOMS

axm1: $\max M 1 \in \mathbb{N} 1$

axm2: $\min P \in \mathbb{N} 1$

axm3: $W R \in \mathbb{N} 1$

END

In the next step, all variables and invariants describing the state of the machine must be defined. Their number depends on the complexity of solved problem and required level of detail. Process of production planning and scheduling is too complex and the construction of the complete Event-B model for this purpose would require thousands of variables and other characteristics. This is just a very simple illustrative example which is planned to be developed by research team in the next years. Firstly, all variables have to be given an initial value via a specific event called "initialization". Each machine works with constants and axioms that were defined in the context using "sees" clause. In our simplified example, the variables, invariants and their initial values can be defined as follow:

\section{MACHINE Production Order} SEES Production

Planning

\section{Limitations}

\section{VARIABLES}

cap_M1 // available

production capacity of machine MI

req_M1 // required

production capacity of machine MI

profit // profit from the order

the order?

Accept // Decision: Accept

INVARIANTS

inv1: cap_M1 $\in 0 \ldots \max M 1$

inv2: $\quad$ req_$M 1 \in \mathbb{N} 1$

inv3: profit $\in \mathbb{N} 1$
EVENTS

inv4: Accept $\in$ BOOL

\section{Initialization:}

THEN

act1: cap_M1:=0,

act2: $\quad$ req_M1 $:=0$,

act3: $\quad$ profit $:=\min P$,

act4: Accept $:=$ FALSE,

END

Then, every action in production planning process must be modelled as a separate guarded event which is automatically proved in order to make the right decision about the acceptance of the order for scheduling. These verification conditions are generated as proof obligations, for example:

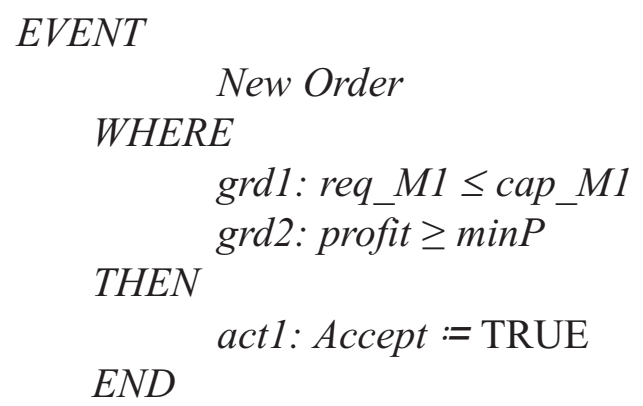

The advantage of Event-B modelling is the possibility to use refinements that enables to add all new details and information into an existing model in a very simple way. For these reasons, it is suitable for solving very complex problems as production planning and scheduling is. The complex Event-B model has to include all critical factors affecting production planning and scheduling which were simply described in Figure 1 as much in detail as possible. Only then the system will be able to make right decisions based on real human expertize modelled in form of mathematical formulas. 


\section{CONCLUSIONS}

The research on achieving expected benefits of an implemented advanced technology for production planning and scheduling in Czech manufacturing companies proved that the level of their achievement is lower than $75 \%$. The consequent interview based qualitative research showed that the major reasons for this fact are individual problems and high complexity of synchronizing all business processes influencing the quality of input data for production planning and scheduling.

Therefore, in the next steps of the research, a simple system model of key factors affecting production planning and scheduling was created as a basic template for the complex abstract mathematical model formulation. Event-B method was chosen for creating the formal mathematical model based on proof obligation because of its simplicity in using refinements and top reliability. This paper illustrates first steps and the main logic of Even-B modelling in the field of production planning and scheduling while the complex model including all important constraints and critical factors will be developed by the author within the next months and years.

\section{Acknowledgement}

This paper is one of contribution to the RVO project "Modelling of effective production and administration processes parameters in industrial companies based on concept Industry 4.0", realized by Department of Industrial Engineering and Information Systems, Faculty of Management and Economics, Tomas Bata University in Zlin.

\section{References}

Abrial, J.R. (2010). Modeling in Event-B: System and Software Engineering. Cambridge, MA, USA: Cambridge University Press.

Belás, J., Bilan, Y., Ključnikov, A., Vincúrová, Z., \& Macháček, J. (2015). Actual problems of business risk in SME segment. Case study from Slovakia. International Journal of Entrepreneurial Knowledge, 3 (1), 46-56.

Goldratt, E.M. (2000). Necessary but not sufficient. Great Barrington, MA, USA: North River Press.

Chen, C., \& Hasan, N. (2008). How to succeed with supply chain planning. Supply Chain Management Review, 12, 30-36.

Jackson, P. (1998). Introduction to expert systems. Boston, MA, USA: Addison Wesley.

Jonsson, P., \& Ivert, L.K. (2015). Improving performance with sophisticated master production scheduling. International Journal of Production Economics, 168, 118130.

Jonsson, P., Ivert, L.K., \& Rudberg, M. (2007). Applying advanced planning systems for supply chain planning: Three case studies. International Journal of Physical Distribution and Logistics Management, 37, 816-834.

Lihong, Q., \& Shengping, L. (2012). An improved genetic algorithm for integrated process planning and scheduling. International Journal of Advanced Manufacturing Technologies, 58, 727-740.

Métayer, C., Abrial, J.R., \& Voisin, L. (2005). Event-B language. Rodin deliverable 3.2. EU Project IST-511599-RODIN.

$\mathrm{Mu}$, Ch. (2013). On information flow control in Event-B and refinement. In Proceedings of the International Symposium 


\section{АНАЛИЗА АЛАТА ПОДРШКЕ ЗА ЕФИКАСНО УПРАВЉАЫЕ ПРОЦЕСОМ У ОБЛАСТИ ПЛАНИРАҢА ПРОИЗВОДЫЕ И ТЕРМИНИРАњА}

\section{Denisa Hrušecká}

\section{Извод}

Планирање и терминирање производње спада међу најзначајније пословне процесе, који значајно утиче на показатеље пословања производних компанија. Постоје бројни информациони системи који подржавају планирање производње и терминирање. Неки од њих су засновани на веома софистицираним алгоритмима за планирање. И поред тога, многе компаније и даље се суочавају са озбиљним изазовима, чак и приликом коришћена професионалних софтверских решења за планирање производње и терминирање. Самим тиме, још увек постоји потреба за доста нових решења и иновација процеса.

Овај рад се бави проблемом управљања процесима у области планирања производње и терминирања. Ова студија описује разлоге лоших перформанси напредних технологија и даје могуће решење у форми системског модела који укључује кључне факторе од утицаја на ефикасност софтвера за планирање. Истраживачки део се заснива на студији која је спроведена у чешким производним компанијама, у форми упитника који је комбинован са интервјуом.

Предложено решење је проширење полазног математичког модела, заснованог на доказним обавезама, које доказују или оповргавају тачност одабраних алгоритама. Ова студија представља основни пример таквог модела и описује његову функционалност, као и утицај на адекватно планирање и терминирање процеса. Наведена студија ће у даљим истраживањима бити унапређена до форме комплексног експертског система заснованом на “Догађај Б” методи.

Кључне речи: Планирање производње и терминирање, управљање процесима, доказивање обавеза, производни процес, производни систем

on Theoretical Aspects of Software Engineering. Birmingham, UK. 225-232.

Neely, A., Bourne, M., Mills, J., Platts, K., \& Richards, H. (2002). Strategy and Performance: Getting the Measure of Your Business. Cambridge, MA, USA: Cambridge University Press.

Noonan, J., \& Wallace, M. (2006). Improved Optimisation through advanced relationship planning. Supply Chain Management: An International Journal, 11, 483-490.

Nyhuis, P., \& Wiendahl, H.P. (2009). Fundamentals of production logistics:
Theory, tools and applications. Berlin, Germany: Springer Publishing.

Šulová, D. (2009). Methods of planning and scheduling in enterprise information systems and their application in a production process management. Zlín, Czech Republic: Tomas Bata University in Zlín.

Vidová, H. (2009). Logistics Controlling. Bratislava, Slovakia: STU.

Weiss, S.M. (1988). Empirical analysis and refinement of expert system knowledge bases in selected topics in medical artificial intelligence. New York, NY, USA: Springer Publishing. 